\title{
Kristen mission \\ og kvinders øgede mulighedsrum
}

\section{Af Anne Folke Henningsen}

Den typiske kvindelige missionar $i$ det 19. og tidlige 20. årbundrede bliver ofte afbildet som en underkuet, tilbageboldende og lidt stramtandet froken. Og hvad med hendes kvindelige konvertitter? Overtog de uden videre en undertrykkende og fremmed religion, eller kan en anden historie skrives frem, bvori de kvindelige missionarers og konvertitters bevidste bestrabelser på at forbedre deves situation bliver tydeliggjort?

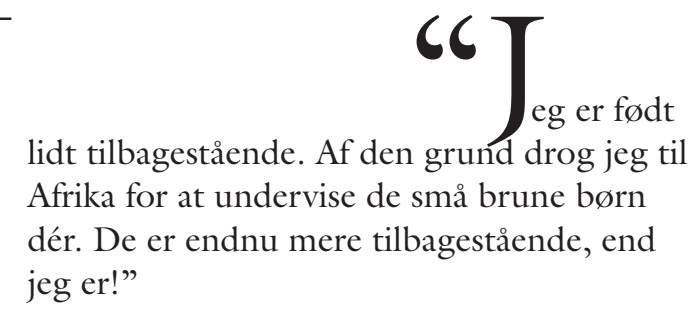

- Den svenske missioner, froken Greta Oblsson $i$ Ingrid Bergmans skikkelse i Sydney Lumets klassiske filmatisering fra 1974 af Agatha Christies 'Murder in the Orient Express' (Min oversettelse).

I denne artikel vil jeg belyse den mulighed for udvidelse af kvinders råderum, kristen ydre mission kan udgøre. ${ }^{1}$ Inden for de sidste årtiers missionshistoriske forskning er der kommet et større fokus både på kvinders virke i missionsgerningen ${ }^{2}$ og på mission som gensidigt konstituerende kulturmøde og som del af en begyndende globalisering. ${ }^{3}$ Den store fortælling om missionsvirksomhed som kolonimagternes forlængede arm i den fortsatte udnyttelse og undertrykkelse af de koloniserede folk er sta- 
dig legitim og væsentlig, men den kvalificeres og nuanceres således for tiden af andre historier med andre perspektiver. I sammenhæng med disse genfortællinger af Missionsnarrationen kan også ses senere tiders historiefaglige bestræbelser på at indtænke de koloniserede og/eller missionsmodtagende folk i de historiske fortællinger: At give stemme til de tilsyneladende tavse objekter for kolonisering eller mission og have blik for deres handlinger og virke. ${ }^{4}$ Her er ambitionen at se de koloniserede og missionsmodtagende folk, som aktivt handlende subjekter i mødet med de vestlige aktører; subjekter med et tydeligt blik for fordele og ulemper ved disses forandringsbestræbelser og med udpræget vilje til strategisk at forsøge at udnytte den nye situation til egne formål. 5

I artiklen ønsker jeg at samle disse to synliggørelsesprojekter i ét ved at vise, hvordan et lille fællesskandinavisk missionsselskab ved navn Den Frie Østafrikanske Mission gav anledning til, at kvinder på begge sider af missionsgerningen - missionærer og konvertitter - kunne indtage nye positioner i hverdag og samfundsliv. Således skal vi se de måder, hvorpå to af selskabets udsendte missionærer, Martha Sanne og Petra Nielsen, gennem deres virke i missionen 'gjorde karriere' og opnåede magt og indflydelse, og hvorledes to af selskabets kvindelige konvertitter, uLoise og uTjubile, udnyttede de nye muligheder, missionen tilbød dem, til at forandre deres livsvilkår radikalt. uLoise og uTjubiles historier tjener som eksemplificeringer af disse nye muligheder for kvinder og skal ikke ses som repræsentative for zulukvindernes reaktion på missionen generelt. Zuluernes agens i mødet med missionærerne var mangfoldige. ${ }^{6}$

\section{SUBJEKTIVERINGSBEGREBET SOM ÅBNENDE VÆRKTØJ}

Det teoretiske udgangspunkt for de analyser, artiklen bygger på, er poststrukturalistisk med særlig vægt på det foucaultske be- greb om subjektivering, 7 som det er blevet videreudviklet af blandt andre Bronwyn Davies $^{8}$ (f.eks. Davies \& Harré 1990). Begrebet benyttes som en strategisk essentialistisk antagelse eller ontological commitment $\mathrm{i}$ den forstand Gayatri Chakravorty Spivak anfører, når hun skriver: “Assuming one's ontological commitment as susceptible to an examination of value coding and then to presuppose a catachrestic name in order to ground our project and our investigation allows us to be thoroughly empirical without necessarily being blind essentialists" (Spivak 1993, 16). Jeg mener, at subjektiveringsbegrebet er en sådan strategisk essentialisme eller et ontologisk engagement. Det er en antagelse om, hvorledes subjekter konstitueres i deres givne historiske kontekster. Men fordi begrebet per definition ikke er fast forankret $\mathrm{i}$ ontologiske fundamenter, må det legitimeres ved dets plausibilitet og evne til at bringe indsigter $\mathrm{i}$ undersøgelsens analyse- og problemfelt på baggrund af det materiale, der er til rådighed.

Begrebet om subjektiveringsprocesser er historisk og geografisk specifikt og ikke transcendent og eviggyldigt, hvilket også ligger i min præsentation af begrebet som en strategisk antagelse om måden, hvorpå subjekter konstitueres. Men eftersom jeg mener, at missionærernes projekt er at skabe 'nye' subjekter, finder jeg det helt rimeligt at benytte et analytisk greb, der har fokus på netop sådanne konstituerende processer. Subjektiveringsbegrebets helt store styrke er nemlig, at det kan indfange forandringerne $\mathrm{i}$ analysernes enkelte personer uden at miste blikket for, at denne enkelte bliver skabt i samspil med og på grundlag af de omgivende diskursive strukturer. Brugen af subjektiveringsbegrebet har således til hensigt at indfange den konstante proces, hvorigennem individer bliver legitime deltagere i den sociale orden og samtidig også de diskursive praksisser, ${ }^{9}$ som deltagere i de respektive diskursive systemer må mestre og udtrykke for at være legitime medlemmer. 
Bronwyn Davies og Rom Harré forklarer begrebets analytiske kraft ved, at det anerkender "both the constitutive force of discourse, and in particular of discursive practices and at the same time recognises that people are capable of exercising choice in relation to those practises" (Davies og Harré 1990, 46). Brugen af begrebet har den store fordel, at det anerkender vigtigheden af de diskursive systemer, som missionærerne opstiller for missionsmodtagerne som betingelser for legitim inklusion, men samtidig også vigtigheden af missionsmodtagernes agens i mødet med disse. Subjektiveringsbegrebet som analytisk værktøj giver således en mulighed for at se de missionsmodtagende folk som txnkende og handlende individer med egne ønsker, mål og strategier, og dette medfører en metodisk sensitivitet over for variationer $\mathrm{i}$ individernes subjektiveringsprocesser. Muligheden for at opnå legitim deltagelse i en ønsket social, kulturel eller religiøs gruppe er snævert knyttet til individernes evne til at optræde kulturelt genkendeligt ${ }^{10}$ og i overensstemmelse med de diskursive praksisser, der forventes af individer tilhørende de forskellige virksomme sociale, kulturelle og religiøse (etc.) kategorier. Subjektiveringsprocesserne kan således ikke ses som baseret på subjekternes helt frie valg: Risikoen for eksklusion fra det ønskede fællesskab lurer konstant, hvis graden af kulturel genkendelighed i subjekternes praksis ikke er høj nok. I det følgende vil jeg derfor vise, hvorledes artiklens fire kvinder - to missionærer og to konvertitter - udfører den balanceakt det er at optræde kulturelt genkendeligt inden for Den Frie Østafrikanske Missions univers og samtidig udvide deres respektive råderum betragteligt.

Men lad os begynde med begyndelsen og se lidt på baggrunden for dannelsen af Den Frie Østafrikanske Mission.

\section{Den Frie Østafrikanske Mission - ET ESKATOLOGISK EKSPERIMENT 1889-1899}

Den Frie $\varnothing$ stafrikanske Mission blev skabt inden for en større skandinavisk vækkelse, der fremkom som reaktion på, hvad nogle kristne så som den henslumrende statskirke-kristendom i midten af det 19. århundrede. Bevægelsens medlemmer kaldte sig selv for 'frie' kristne og i spidsen, og som energisk drivkraft, fandtes den svensk-amerikanske missions-katalysator Fredrik Franson.11 I Fransons kristendomsforståelse havde missionen - navnlig den ydre 'hedningemission' - en meget central plads. At missionen var hjertebarnet hang sammen med Fransons eskatologiske overbevisning, idet Jesu andet komme for Franson var en konkret og nært forestående begivenhed. Han daterede kløgtigt nok aldrig præcist, hvornår dette skulle finde sted, men han forventede, at det ville indtræffe inden for et par år. Derfor havde denne verdens alvorlige, omvendte kristne travlt (Larsen 1974, Christensen 1927, 31 og 138, Larsen 1965, Diesen og Hagelia 1984).

Troen på nødvendigheden af et vist hastværk i gerningen medførte, at kvinder fik en relativt stor plads i den fransonske version af kristen ydre og indre mission: Enhver stemme for Herren talte, og hvis kvinder viste gode egenskaber udi sjælefiskeriet, skulle de naturligvis udnytte dem på bedste vis. Således var de bibel- eller evangelistkurser han i 1880'erne afholdt i de skandinaviske lande åbne for både mænd og kvinder. Franson forfattede også et forsvarsskrift for kvinders aktive og direkte evangeliseringsarbejde: Eders Døtre skulde profetere (Franson 1890). Med dette skrift ønskede han tilbagevise kritikeres påstande om, at det skulle være bibelstridigt for kvinder at foretage sådant arbejde. I det hele taget var der i de frie kristne bevægelser en udbredt opfattelse af, at kvinder var meget vigtige deltagere i evangeliseringsarbejdet (Franson 1890, 10, Larsen 1965, Larsen 1976), hvilket også afspejler sig i kønssammensætnin- 
Den Frie Ostafrikanske Missions første ni missionerer forlod den 4.juli 1889 Kristiania med kurs mod Natal $i$ det nuverende Sydafrika 
gen af de i første omgang udrejsende missionærer for Den Frie Østafrikanske Mission - seks kvinder og tre mænd drog $\mathrm{i}$ 1889 afsted til Afrika.

Det er dog væsentligt at påpege, at Franson i denne sag skelner skarpt mellem gifte og ugifte kvinder: De gifte er underlagt deres husbonds autoritet - hvis altså denne er en levende, fri kristen - og skal ikke blande sig i det udadvendte arbejde, men snarere passe hus og hjem. Men naturligvis skal de gifte kvinder også i det omfang deres husholdningsarbejde tillader det være med i den fortsatte evangelisering af folket - ved deltagelse i opbyggelige møder og eventuelt også ved at være behjælpelige med afholdelsen af sådanne (Franson 1890, 25-26, Larsen 1965). Og det var præcis en sådan arbejdsdeling, det oprindeligt var tænkt skulle sættes i værk på Den Frie Østafrikanske Missions nye missionsstation i Natal: De to gifte kvinder skulle holde hus og kun i begrænset omfang deltage i evangeliseringsarbejdet, mens de resterende fire kvinder skulle indgå på lige fod med mændene; dog var de udpegede ledere af missionen mænd, nemlig brødrene Olaf og Jacob Wettergren. ${ }^{12}$

Som vi skal se, blev denne på forhånd planlagte arbejdsfordeling af flere årsager og på flere måder forstyrret i løbet af Den Frie Østafrikanske Missions 10 år i Natal og Zululand.

\section{KARRIEREMULIGHEDER I MISSIONEN - HVIDE KVINDERS ØGEDE MAGT, INDFLYDELSE OG RÅDERUM}

Som nævnt i indledningen vil jeg i dette afsnit vise to eksempler på de muligheder for forandring, som missionsgerningen kunne udgøre for de kvindelige missionærer. Det er ingen overraskelse, at kvinderne i højere grad end mændene kunne udnytte opholdet på missionsstation til at forbedre deres verdslige position, eftersom mændene i udgangspunktet besad lederpositionerne, men det er alligevel værd at pointere, at foran- dring kunne finde sted for kvinderne - og faktisk gjorde det; at de ikke blot lod sig nøje med en underordnet position, når muligheden bød sig til at indtage en bedre, og at de selv arbejdede hådt for at disse muligheder skulle komme til at byde sig.

\section{Petra 'Mutter' Nielsen: 'Elefantkvinden' - leder og husholderske}

Enkefru Petra Nielsen solgte i 1890 sin forretning og alt hvad hun ejede i København og drog til Afrika med det fortsæt at være husmoder for Den Frie Østafrikanske Mission; et ganske kønstraditionelt valg af beskæftigelse i missionen. Hun bragte med sin ankomst stor glæde blandt både sorte og hvide på missionsstationen "Ekutandaneni." Zuluerne beundrede hende meget og gav hende et åbenbart hædrende tilnavn 'elefantkvinden' (Martha Sanne i Missioneren nr. 30, 1891). Missionærerne var også godt tilfredse, fordi hendes hårde arbejde med husholdningen frisatte de andre kvindelige missionærer til egentligt missionsarbejde (Olaf Wettergren i Missioneren nr. 40, 1891). Blandt missionærerne gik hun således under tilnavnet 'Mutter' .

I 1893-1894 var 'Mutter' på rundrejse i Skandinavien for at vække interessen for Den Frie Østafrikanske Missions gerning i Natal. Missionærerne var fuldstændig afhængige af bidrag fra frie kristne missionsvenner i hjemlandene, og det var derfor katastrofalt for dem, når interessen for deres mission dalede. Både missionærerne og diverse støtter i hjemlandene havde forsøgt at forøge interessen og giverlysten blandt de skandinaviske venner, men da det ikke gav det store resultat, blev det besluttet at sende 'Mutter' afsted. Hun skulle med sine foredrag forsøge at drage de frie kristnes fokus til Den Frie Østafrikanske Mission.

Imens 'Mutter' således var i Skandinavien foregik en korrespondance mellem Centralkomiteen i Kristiania og folkene i Natal, hvoraf det fremgik at missionens leder Olaf Wettergren var afveget $\mathrm{i}$ sin tro, og han fraflyttede stationen i 1894 og bosatte sig 
med ligesindede i Durban (Redegørelse fra Centralkomiteen, april 1895, trykt i Missioneren nr. 17, 1895). Efter dette brud mellem Olaf og Den Frie Østafrikanske Mission bemyndigedes Petra 'Mutter' Nielsen af Centralkomiteen i Kristiania til at være missionens leder (Ti-aarsberetning for den frie Østafrikanske Mission). Ifølge Emil Larsen arbejdede 'Mutter' selv aktivt for at iværksætte denne udnævnelse (Larsen 1976, 61-62). Det er uklart, hvilket kildemateriale denne antagelse bygger på, men den er ingenlunde urimelig: Det er meget muligt, at 'Mutter' har gødet jorden for sin overtagelse af ledelsen enten ved direkte samtaler med Den Frie Østafrikanske Missions komite i Kristiania eller indirekte gennem sin - formentlig - kompetente håndtering af aktiviteterne $\mathrm{i}$ hjemlandene.

Da gælden for købet af missionsstationen "Ekutandaneni" var betalt ud i 1896, blev skødet på grunden overdraget til Petra Nielsen af Centralkomiteen gældende så længe hun var i missionens tjeneste (Note fra medlem af Centralkomiteen, Mathias Hansen, trykt i Missioneren nr. 44, 1896). Martha Sanne gav ifølge den norske historiker Hanna Mellemsether Petra Nielsen følgende skudsmål: at hun var en "modig og energisk kvinde, med naadegaver til at styre" (Mellemsether 1995, 160).

Således udviklede Petra 'Mutter' Nielsens missionsvirksomhed sig fra den traditionelle rolle som husmoder til den for en kvinde helt usædvanlige position som leder af en missionsstation. Hele tiden hjalp hun desuden til med skoleundervisningen på stationen. Under boer-krigen flygtede de tilbageværende missionærer til Durban og her åbnede 'Mutter' et pensionat, som hun drev frem til sin død i 1907. På dette pensionat boede naturligvis Fredrik Franson, da han på sin store missionsrejse jorden rundt gjorde holdt i Durban, og han benyttede stedet til afholdelse af møder og evangelistkurser. Ringen var sluttet (Larsen 1976, 60-62).
Martha Sanne - skolefroken og eventyrerske Den norske frøken Martha Sanne drog ud som en af de oprindeligt udsendte ni missionærer for Den Frie Østafrikanske Mission, og ved at gøre dette vinkede hun som de fleste af de andre missionærer - farvel til en tryg middelklassetilværelse i det velkendte Norge. Martha var ansat som lærerinde på en døveskole i Kristiania, men fulgte altså sit kald om at drage ud som missionær, da muligheden i 1889 bød sig i regi af Den Frie Østafrikanske Mission ${ }^{13}$. Martha var fra begyndelsen energisk i missionens tjeneste på trods af sit svage helbred, der ofte tvang hende på rekreationsophold i sundere omgivelser end på "Ekutandaneni." Hun skrev ofte hjem til Missionærens læsere om sine evangeliseringsture, og af disse fremgår det, at hun - i hvert fald i egen selvrepresentation - var ganske frygtløs og ikke det fjerneste tilbageholdende. Således var Martha i 1891 på besøg i en nærliggende $\mathrm{kraal}^{14}$ for at tale Guds ord med beboerne. I mændenes hytte blev der drukket $\varnothing \mathrm{l}$ - noget der ifølge missionærerne var en ganske normal beskæftigelse blandt zuluerne; de yndede i høj grad at afholde såkaldte 'øllag'. Martha hørte de højlydte samtaler fra hytten, men kravlede uanset ind gennem hyttens åbning - kvinder var ellers ikke velsete i mændenes hytter. Vel ankommet i den røgfyldte hytte begyndte hun sin prædiken for de målløse zulumænd (Martha i Missionaren nr. 32, 1891).

Efter 'Mutters' ankomst fik de andre kvindelige missionærer som nævnt mere tid til selve evangeliseringsarbejdet. Dette udnyttede to af de ugifte kvindelige missionærer, Martha Sanne og Georgine Anstensen, til at drage ud på en længere evangelisttur. Dette vakte stor forbavselse blandt zuluerne, der ikke kunne begribe, at kvinderne ikke var bange for at rejse så langt og så længe helt alene, for slet ikke at tale om at overnatte alene i oksekærren. Men Martha og Georgine forklarede tvivlerne, at de ville forlade sig på deres Gud til at holde hånden beskyttende over dem. Undervejs 
på turen overraskedes Georgine af en giftig slange, men hun tilkaldte Martha og efter at have fundet et par kxppe som våben, gik de to løs på slangen og "knækkede" den (Martha i Missioneren nr. 37-38, 1891). Der er ikke meget skræmt, stramtandet tilbageholdenhed over disse to predikende eventyrersker!

Fra begyndelsen var det planlagt, at Den Frie Østafrikanske Mission skulle drive skole på stationen i Natal, men efter ankomsten opstod der principiel uenighed om det bibelsk korrekte i sådan virksomhed. Det var en bitter strid, der medførte splittelser i organisationen, og i hvilken der fremførtes både praktiske, strategiske og teologiske argumenter på begge sider. Et par eksempler på hver af positionerne kan give en idé om konfliktens indhold.15 For de undervisningskritiske taler Pastor Otto Witt (oprindeligt udsendt af den svenske statskirkes mission):

"Som Missionen i Almindelighed drives, saa lægges al Vægt paa den opvoksende Slægt og aabent udtales der jo, at Haabet staar til Børnene. Men om nu Herren kommer inden den opvoksende Slægt er kommet til Modenhed? Havde Herren givet sine Disciple den Opgave at civilisere Verden, saa havde den nuværende Fremgangsmaade uden Tvivl været den rette. Men det har Han ikke gjort. Meget mere siger Han i sit Ord, at den verdslige Dannelse er til Hinder for Hans Rige. Derfor findes ikke i Jesu Befaling til sine Disciple den ringeste Hentydning til at de i Hedningeverdenen skulle oprette Skoler og Børnehjem [...]" (Witt på "Ekutandaneni," februar 1890, trykt i Missioneren nr. 16, 1890).

Den Frie Østafrikanske Missions leder Olaf Wettergren er derimod tilhænger af skoleundervisningen på missionsstationen:

"Vi tror, at om der end er en stor Fare ved at proppe Børnene og Ungdom med overflødig Kundskab og saaledes forsømme det ene vigtige at forkynde Evangeliet og da drive selve
Skolegjerningen til en ubibelsk Yderlighed, vi dog er berettiget til at give disse uvidende Børn en simpel Lærdom som at læse, skrive, lidt Haandarbeide og Regning. [...] Herrens Aand arbeider paa dem, og jeg er forvisset om, at Skolegjerningen her fremlagt dagligt for Gud af eder og os i vore Bønner skal blive til virkelig evig Velsignelse" (Olaf i Missioneren nr. 12 1892).

Udover Olaf fremstår Martha Sanne som en af de stærkeste tilhængere af skolevirksomheden.16 Det er ikke mærkeligt, dels havde hun tidligere virket som lærerinde $\mathrm{i}$ Kristiania, og dels var netop skolevirksomheden et af de områder, hvor missionærerne - mænd som kvinder - fandt, at kvinderne særligt kunne gøre nytte: "Vi tror det er rigtig at undervise Børn og tror at det er netop her, Søstrene kan benyttes i Arbeidet herude" (Olaf Wettergren i Missioneren nr. 19, 1892). Striden endte med, at Den Frie Østafrikanske Mission i 1892 oprettede en skole på hovedstationen Ekutandaneni, og Olaf bemærkede i en redegørelse om skolen og dens principper, at "Skolen er nu overdraget til Søstrene Sanne og Anstensen" (Missioneren nr. 19, 1892). I redegørelsen understregedes det desuden, at mændene udelukkende skulle blande sig i skolens anliggender på opfordring fra kvinderne.

I 1895 besluttedes det efter længere tids overvejelser fra både ledelsen i Kristiania, på "Ekutandaneni" ('Mutter') og Martha Sanne selv, at hun skulle fortsæette sin skolevirksomhed på en satellitstation i det nærliggende område uMhlali. Martha drog afsted med sin trofaste hjælperske, den kristnede zulu uLoise, og de to holdt skole i området indtil 1901, hvor en 'Gouvernementsskole' oprettedes i nærheden, og konkurrencen blev for hård (Mellemsether 1995, 175). Martha Sanne fungerede altså som skoleleder på hovedstationen "Ekutandaneni" med Georgine Anstensen ${ }^{17}$ fra 1892-1895 og siden som eneste leder af satellitstationen ved uMhlali, der etableredes med skoleundervisning som det primære 
Fra sidste Daabshandling ved Ekutandaneni. Missioneren nr. 121902. 
mål. Men denne position som skoleleder blev hende ikke foræret; hun måtte i høj grad selv kæmpe og arbejde for, at det overhovedet blev en mulighed.

Den Frie Østafrikanske Mission befandt sig således i 1895 i den højst usædvanlige situation, at begge dens missionsstationer blev ledet af kvinder. 'Mutter' på grund af sin styrke ('elefantkvinden') og gode lederegenskaber og Martha på trods af sin fysiske svaghed, men med styrke i sit store engagement i og talent for skoleundervisning. To forskellige, men parallelle karriereveje for to forskellige, men ligesindede kvinder blev således muliggjort af arbejdet i Den Frie Østafrikanske Mission. Ingen af de to kvinder udfordrede tilsyneladende de eksisterende kønshierarkier så meget, at det umuliggjorde deres opstigen i graderne. De har da også holdt sig inden for traditionelle kvindearbejdsområder - husholdning og skoleundervisning - men med den forskel, at de samtidig administrerede og ledede hver sin missionsstation - og i 'Mutters' tilfælde på trods af mandlig tilstedeværelse.

\section{OM CIVILISERING AF DE 'VILDE'}

Inden vi vender os mod de konkrete fremstillinger af to zulukvinders motivation for at konvertere og deres forandrede livsvilkår efter den religiøse konversion, præsenteres her nogle af målene med kristen mission og den tvivl og skepsis, som missionærerne udførte deres arbejde med - for havde de 'vilde' overhovedet potentialer til at forandres og forbedres? Var arbejdets sparsomme frugter sliddet, sygdommene og afsavnene værd?

Som så mange andre missionsselskaber, der var aktive i Afrika på denne tid, var missionærerne fra Den Frie Østafrikanske Mission skrevet ind i og trak på en koloniel diskurs, hvori race spillede en væsentlig rolle for synet på menneskers potentialer. ${ }^{18}$ Sorte mennesker ansås således som mindre udviklede end hvide. Det springende punkt var, hvorvidt man mente, at de 'vilde' var dømt til evigt at være næsten som dyr (som man betragtede dem som qua deres 'vildskab'), eller om de havde potentialer til at blive 'rigtige' mennesker som de hvide med god, kristen moral og levevis. Og denne sidste position indtog langt de fleste missionærer. Det gav således mening at drage ud på missionsfærden, for et gennemgående træk i missionærernes refleksioner var de 'vildes' ukultiverede og utæmmede menneskelighed - en menneskelighed der grundlæggende var god, men manglede det vestlige lys. En vigtig stemme i denne debat blev de biologiske videnskaber, der med stor autoritet kunne udtale sig om menneskets natur og de muligheder, de forskellige mennesker, og i særdeleshed de forskellige racer, havde for udvikling og forbedring. Fra disse videnskaber kom også opfattelsen af, at menneskelighed kan gradbøjes og skaleres, således at det blev muligt at tegne et billede af menneskeslægtens udvikling med den sorte nederst på skalaen og den hvide mand som det perfektionerede øverste mål. ${ }^{19}$

Men selv de kristne missionærer, der drog ud for at forsøge at forbedre og 'løfte' de vilde mennesker, havde konstant en mistanke om, at det egentlig var omsonst - at selveste biologien var imod dem. Således kan denne tvivlende og undrende position også genfindes hos missionærerne fra Den Frie Østafrikanske Mission:

"Mon Adam og Eva har havt samme tilbøielighed til hvile og uvirksomhed som kafferne [missionærernes ord for zuluerne] eller har de havt en anden drivkraft i sig. Hvoraf kommer det at de forskjellige menneskeracer staar paa saa forskjelligt standpunkt? Er sorte folk en mere underordnet race i intellektuel henseende end hvide, siden de ikke hæver sig. Er det evnen som fattes eller hvad?" (Martha Sanne, dagbog 1893).

Men på trods af al tvivl arbejder Den Frie Østafrikanske Mission selvfølgelig på at 'løfte' zuluerne ud af deres hedenske trældom og blive 'rigtige' mennesker. I det føl- 
gende skal vi møde to af de kvinder, hvis liv blev forandret radikalt efter mødet med Den Frie Østafrikanske Mission.

\section{NyE MULIGHEDER FOR KONVERTEREDE ZULU-KVINDER}

Den Frie Østafrikanske Mission forsøgte gennem sin virksomhed i Natal og Zululand at forandre de zuluer, de interagerede med. Den forsøgte at gøre dem til 'rigtige' mennesker, til kristne. Men selvom missionærerne udstak rammerne for, hvad deres konvertitter kunne og skulle, havde de ikke fuldstændig kontrol med, hvorledes de nye muligheder, deres aktiviteter skabte, blev udnyttet. Mary Louise Pratt udtrykker dette forhold således:

While subjugated peoples cannot readily control what emanates from the dominant culture, they do determine to varying extents, what they absorb into their own, and what they use it for (Pratt 1992, 6).

I det følgende skal vi møde to zulukvinder, der på hver sin måde benyttede deres nye religiøse tilhørsforhold til at forandre deres liv. Men det er vigtigt at huske på, at når missionærerne beskriver, hvorledes deres kvindelige konvertitters livssituation gennem kristendommen forbedres, er det ikke uskyldigt: Kristne missionærer - både fra Den Frie Østafrikanske Mission og mere generelt - benyttede ofte mere eller mindre autentiske tragiske beskrivelser af kvindeundertrykkelse blandt de oprindelige folk til at legitimere deres eget kristne forandringsprojekt; til at vise i hvor høj grad der var behov for deres arbejdsindsats for at løfte de trælbundne hedninger fra deres uværdige liv og op til et xgte kristent kønsforhold, hvor kvinden stod som mandens medhjælper og ikke hans slavinde. ${ }^{20}$ Som Martha udtrykte det i sin beskrivelse af en kristnet mand, hvis eneste kone var død: “Tænk, nu sidder han der alene, gaar og arbeider alene, istedet for som Landets Skik er, at Manden sidder som en liden Konge i sin Kreds omgiven af Hustruer og en stor Skare Børn" (Missioneren nr. 3, 1892). Missionærerne havde således en egeninteresse i dels at fremstille zulusamfundene som kvindeundertrykkende og dels at understrege de positive og 'frigørende' virkninger af deres egen indsats.

\section{uLoise}

Marthas trofaste hjælperske uLoise var Den Frie Østafrikanske Missions første døbte. Hun var vokset op på en missionsstation men forlod efter sit ægteskab med en polygyn 'hedning' den kristne vej. Da missionærerne anlagde "Ekutandaneni" i umiddelbar nærhed af hendes bolig, blev hun atter interesseret i den kristne lære og begyndte at komme til deres møder og lod sig snart genkristne. Men hendes kristning og dåb gav hende problemer blandt familie og venner, og hun anklagedes på et tidspunkt for hekseri - en meget alvorlig anklage, der kunne straffes hårdt. Med denne anklage som anledning gik uLoise til den engelske Magistrat - den øverste myndighed i området - for at bede om skilsmisse, og helt exceptionelt fik hun den. Hun flyttede derefter ind som medhjælper på "Ekutandaneni" med sine børn. Ifølge historikeren Norman Etherington $(1978,67,174)$ udgjorde de kristne missionsstationer i Natal og Zululand et tilflugtssted for zuluer, der på den ene eller anden vis var raget uklar med familie, venner og slægt. Sådanne flygtninge var således ofte blandt konvertitterne på missionsstationerne, og uLoises historie kan næsten kaldes en klassiker. Dog med den væsentlige undtagelse, at det netop var uLoises genfundne kristendom, der bragte hende på kant med slægten, og hun således allerede var konverteret ved sin indflytning på "Ekutandaneni."

Men missionsstationerne udgjorde altså et tilflugtssted for 'afvigere' i zulusamfundene. $\mathrm{Og}$ efterhånden som rygterne om $\mathrm{de}$ nye muligheder, missionsstationerne tilbød utilfredse og/eller uønskede zuluer, spred- 
tes, øgedes tilstrømningen af flygtninge til stationerne. Det var særligt unge kvinder på flugt fra uønskede xgteskaber, der søgte beskyttelse og ophold hos missionærerne. ${ }^{21}$ Missionsstationerne udgjorde en særdeles attraktiv redningsplanke for disse unge kvinder, fordi enlige kvinder ikke havde nogen selvstændig eller legitim 'plads' i zulusamfundene - et forhold Martha Sanne med undren påpeger.

uLoise viede sit liv til Den Frie Østafrikanske Mission - uLoise tog med, da Martha Sanne i 1895 flyttede til uMhlali, og hun udtalte ved den lejlighed: "Vi to skal dø sammen" (Mellemsether 1995, 165) og fandt således en plads i samfundet, der kunne opfylde hendes ønsker for sit liv og hendes nye religion, og selvom det i netop hendes tilfælde var missionærerne, der både foranledigede hendes behov for beskyttelse og kunne tilbyde denne, kan uLoise udgøre et billede på den nye mulighed et ophold på missionsstation udgjorde for zulukvinder, der ikke ønskede at eller kunne leve op til zulusamfundenes krav og normer - eksempelvis med hensyn til de for samfundsopbygningen og $-\varnothing$ konomiens meget vigtige polygyne xgteskaber (Etherington 1978, Marks 1970).

\section{uTjubile}

uTjubile var et produkt af Martha Sannes skoleundervisning på "Ekutandaneni." Ved sin dåb aflagde hun sammen med de andre dåbsaspiranter vidnesbyrd om deres personlige tro på Jesus Kristus, og med denne trosgerning påtog de sig kristendommen fuldt ud - til deres familiers store fortrydelse (Petra i Missioneren nr. 50 1894). uTjubile gik dog et skridt længere end de fleste andre, da hun til missionærernes store glæde selv blev missionær. At skabe missionærer ud af zuluerne var Den Frie $\emptyset_{\text {stafri- }}$ kanske Missions største håb og ønske, fordi de var overbeviste om, at 'indfødte' ville være de bedst skikkede til at få omvendt folkene. Dette var allerede missionsdirektør Fredrik Franson inde på, inden de tog af- sted, og flere gange skrev de forskellige missionærer hjem om netop dette, at deres ønske var at få indfødte prædikanter for at få omvendt så mange som muligt. uTjubile var Den Frie Østafrikanske Missions første og eneste zulu-missionær, men hun påtog sig til gengxld at drage ud i et meget fjernt område, hvor der ingen kristne missionærer havde været før. Vi hører desværre intet om, i hvilket omfang hendes indsats var succesrig eller ej, men Petra 'Mutter' Nielsen citeres af M. Hansen i Missioneren nr. 7, 1896 for følgende vurdering: "En af deres omvendte Skolepiger, Tjobile, er flyttet til et Sted, hvor ingen Mission er, og der sammenkalder hun folk og vidner for dem om Jesus og det gjør stort Intryk paa Hedningene. Maa Gud velsigne hende, at hun lig den samaritanske Kvinde maa føre mange Syndere til Jesus, og de Indfødte vil naturligvis blive de bedste Missionærer". uTjubiles historie er interessant som endnu et eksempel på en individuel realisering af missionærernes kristne subjektiveringstilbud: uTjubile går på en måde endnu længere end uLoise, der flyttede ind på stationen, fordi uTjubile arbejdede alene, men det kan også tænkes, at det netop gav hende en vis frihed i sin praksis, som hun ikke ville have fået, hvis hun var flyttet ind som missionær på stationen ved uMhlali eller på "Ekutandaneni."

\section{OPSAMLING}

I denne artikel har fokus været på to underbelyste synliggørelsesprojekter: Kvinders roller og karrieremuligheder i den ydre mission og konvertitternes aktive deltagelse i udformningen af deres egne nye, kristne liv - i deres subjektiveringsprocesser.

Martha Sanne og Petra 'Mutter' Nielsen blev draget frem for at vise, at alternativer til det $\mathrm{i}$ indledningen skitserede missionærbillede eksisterer og desuden, hvorledes det var muligt for to kvinder fra Den Frie Østafrikanske Mission at skabe sig karriere inden for missionen - Martha blev mere el- 
ler mindre selvstændig missionsskoleleder på en afsidesliggende satellitstation, mens Petra overtog ledelsen af hele missionens virksomhed, på trods af mandlig tilstedeværelse på missionsstationen. At aktiviteterne foregik blandt 'vilde' folk, har formentlig fremmet Petras muligheder for formelt ledelsesansvar. Den norske velhaver Cathrine Juells historie i Danmark kan i hvert fald pege i dén retning: Hun gjorde en enorm indsats blandt de 'frie' kristne og for oprettelsen af Det Danske Missionsforbund (tidligere Frimissionen), men fik aldrig formelt ansvar. $^{22}$

Artiklens to konvertiteksempler, uLoise og uTjubile, er blandt Den Frie Østafrikanske Missions succeshistorier, fordi de på hver deres måde bidrog til og videreførte missionærernes projekter. Men selvom uLoise og uTjubile var pligtopfyldende konvertitter, var udlevelsen af deres nye kristne tro ikke direkte og fuldstændigt dikteret og pålagt dem af missionærerne. Ligesom mange af de zuluer, der var i kontakt med missionen, men ikke gik i dennes tjeneste, var uLoise og uTjubile selv aktive deltagere $\mathrm{i}$ forhandlingerne om deres nye religiøse livsførelse og kunne således være med til at optimere deres situation. Og de forhandlingsindlæg, de fremførte, var baseret på egne behov, beskæftigelse og tilhørsforhold: uLoise fik et tilflugtssted fra anklagerne om hekseri, og uTjubile fik muligheder for at rejse omkring alene, hvilket ikke havde kunnet lade sig gøre uden den kristne missionsgernings beskyttende legitimitet.

\section{Noter}

1. Dette perspektiv er ikke fremtrædende i min specialeafhandling (Henningsen 2003), hvis materiale ellers ligger til grund for denne artikel, men jeg finder, at det er en vigtig pointe, som det er oplagt at belyse i en publikation med temaet "Religion". Jeg takker den anonyme referee såvel som redaktør Hilda Rømer Christensen for værdifulde kommentarer og forbedringsforslag i forbindelse med færdiggørelsen af artiklen.

2. F.eks Predelli 2000+2001, Okkenhaug 1999, Mellemsether 1995.

3. F.eks. Hall 2002, Comaroff 1991-1997.

4. Som eksponent for et sådant projekt kan nævnes den indiske Subaltern Studies Group (Guha (ed.) 1983-1987).

5. Se f.eks. Pratt 1992, som dog beskxftiger sig med rejseberetninger og ikke mission, men der findes imidlertid mange både teoretiske og empiriske paralleller.

6. I specialeafhandlingen behandles dette forhold i dybden (Henningsen 2003).

7. Jvf eg. Foucault 1998, opr. 1976, s. 60.

8. For en introduktion til Davies, se Søndergaard 2000.

9. Jeg benytter begrebet 'diskursiv praksis' for at signalere, at det ikke blot refererer til tale og skrift men også til alle andre slags handlinger; at diskurser er sociale aktiviteter, der konstituerer virkeligheder jf. Simonsen $(1996,72)$.

10. Jf. Butler (1990, 17).

11. For historiske fremstillinger af de 'frie' kristne bevægelser i Skandinavien se f.eks. Larsen 1965, Diesen 1980, Diesen \& Hagelia 1984.

12. Da Jacob allerede dør i slutningen af 1889 , er Olaf i praksis ene leder af Den Frie Østafrikanske Mission.

13. Se Mellemsether 1995 som er biografi om Martha Sanne.

14. Missionærernes noget kolonialt belastede ord for zuluernes bosætninger - det betegner egentlig kvægaflukket i bosætningens midte!

15. For yderligere behandling af skolestriden se diverse indlæg i Missionoren 1890-1892 samt Henningsen 2003, 52-64.

16. Se f.eks hendes betragtninger i Missionaren $\mathrm{nr}$. 39, 1895. Tilhængerne får desuden støtte fra Centralkomiteen i Kristiania, f.eks. i Missionaren nr. $31,1895$.

17. Georgine giftede sig i 1892 med en missionær Feyling fra et andet selskab og forlod således Den Frie Østafrikanske Missions tjeneste.

18. Se f.eks. Comaroff og Comaroff 1991-1997.

19. Som interessant parallel kan i forbifarten nævnes Amit Chaudhuris minde om sin skolegang i en protestantisk skole i Bombay. En anskuelsestavle af evolutionsnarrationen med udviklingen fra abe til menneske prydede klasseværelsets ene væg: "By the time it [the ape] had reached the apogee of its heigth and straight-backedness, and taken a stride forward, its appearance had improved noticeably; it had become a Homo sapiens, and also, coincidentally, European” (Chaudhuri 2004). 
20. Se f.eks. Mellemsether 1995, 143-144, Etherington 1978, 59-60.

21. Som eksempel kan nævnes missionær Emilie Häggbergs hjerteskærende beretning om den unge zulupige Udomai, der flygtede til en missionsstation for at undslippe et uønsket ægteskab, hvorefter hendes familie opsøgte hende på stationen og forsøgte at tvinge hende med hjem igen (Missionaren nr.18, 1892).

22. Biografi om Cathrine Juell, se Larsen 1976.

\section{UTRYKTE KILDER}

Privatarkiv 410, Riksarkivet i Oslo: Det Norske Misjonsforbunds Arkiv, arkivæske nr. 12 og arkivæske nr. 39 (mappen 'Korrespondanse 18891891' indeholder korrespondancer omhandlende DFØM i unummererede men ofte navngivne foldere; mappen 'Martha Sannes dagbøger fra 18901923 korrenspondanse 1891-1899' indeholder Martha Sannes dagbøger, hvoraf den første er temmelig skadet af termitter).

\section{TRYKTE KILDER}

- Franson, Fredrik (1890): Eders Døtre Skulde Profetere. Bibelkvindehjemmets Forlag, Kristiania. - Larsen, Emil (1974): Franson og himmeluret. Den kristne Bokringen, Filadelfiaforlaget, Oslo. - Missioneren - Evangelisk kristeligt Ugeblad (1. årgang (1889) bar det navnet: Missioneren - Evangelisk kristeligt Blad), fra prøvenummer december 1888 til nr. 52 1899, samt nr. 121902

- Tiaarsberetning for Den frie østafrikanske Mission fra 1ste januar 1889 til 30 te juni $1899 \mathrm{v} /$ Centralkomiteens Sekreter, M. Andersens Bogtrykkeri, Laurvig 1899 (findes i Privatarkiv 410, Riksarkivet i Oslo, arkivæske nr. 12)

\section{LITTERATUR}

- Butler, Judith (1990): Gender Trouble. Routledge, London.

- Chaudhuri, Amit (2004): "In the Waiting-Room of History". I: London Review of Books, vol. 27, June 24 .

- Christensen, John (1927): Verdensmisjoneren F.

Franson. Det Norske Misjonsforbunds Folag, Oslo - Comaroff, John \& Jean (1991-1997): Of Revelation and Revolution. The University of Chicago Press, Chicago

- Davies, Bronwyn \& Rom Harré (1990): "Positi- oning: The Discursive Production of Selves" I: Journal for the Theory of Social Behaviour, vol 20, nr 1 .

- Diesen, Ingulf (1980): Veiryddere. Ansgar, Oslo - Diesen, Ingulf \& Hallvard Hagelia (1984): Veien videre: Det Norske Misjonsforbund 1884-1984. Ansgar, Oslo

- Etherington, Norman (1978): Preachers, Peasants, and Politics in Southeast Africa. 1835-1880. Royal History Society, London.

- Foucault, Michel (1998, opr. 1976): The History of Sexuality. vol I, Penguin Books.

- Guha, Ranajit (Red.)( 1983-1987): Subaltern studies: Writings on South Asian history and society $I-V$. Delhi: Oxford University Press.

- Hall, Cathrine (2002): Civilising Subjects. The University of Chicago Press,

- Henningsen, Anne Folke: 'En straalende Juvel $i$ Frelserens Krone' - Civiliseringsbestrabelser i Den Frie Østafrikanske Missions Frelsesvirksombed i Natal og Zululand 1889-1899, specialeafhandling ved Institut for Historie og Samfundsforhold, Roskilde Universitetscenter 2003; til udlån på Roskilde Universitetsbibliotek

- Larsen, Emil (1965): Historiske studier over kirkelige og frikirkelige brydninger. Tro og Liv, København.

- Larsen, Emil (1976): Kvinde, din tro er stor. Tro og Liv, København.

- Marks, Shula (1970): Reluctant Rebellion. Clarendon Press, Oxford University Press

- Mellemsether, Hanna (1995): Kvinne $i$ to Verdener. Senter for Kvinne- og Kjønnsforskning, Skriftserie 1/95, Universitetet i Trondheim.

- Okkenhaug, Inger Marie (1999): The quality of heroic living, of high endeavour and adventure Universitetet i Bergen.

- Pratt, Mary Louise (1992): Imperial Eyes. Travel Writing and Transculturation. Routledge, London

- Predelli, Line Nyhagen ( 1999): "Emansipasjon av kvinner hjemme og ute" i: Warring, Anette (red.) (2000): Køn, religion og kvinder $i$ bevagelse. Konferencerapport fra det VI. Nordiske Kvindehistorikermøde, Tisvildeleje, Kvinder på Tværs, Roskilde Universitetscenter.

- Predelli, Line Nyhagen: "Missionary women and feminism in Norway", 1906-1910, i: Nora, nr.1, 2001, vol. 9, Taylor and Francis 2001. - Spivak, Gayatri Chakravorty (1993): Outside in the Teaching Machine. Routledge, London. - Søndergaard, Dorte Marie: "Kønnet Subjektivering”. i: Kvinder, Køn og Forskning, nr.1, 2000. 


\section{SUMMARY}

The article has a double objective: to emphasize the diversity of the roles and career opportunities that foreign missionary activities could provide for female missionaries, and to show how converts spawned by these missionary endeavours used their new religious affiliation and faith to actively change their worldly positions and possibilities. The analy- ses are based on published and unpublished material from the tiny Scandinavian mission society 'Den Frie Østafrikanske Mission', that worked in Natal and Zululand in present day South Africa from 1889-1899.

Anne Folke Henningsen, cand.mag., ph.d.-stipendiat, Institut for Historie og Områdestudier, Århus Universitet. 